\title{
Prime controls on Archaean-Palaeoproterozoic sedimentation: Change over time
}

\section{P.G. Eriksson ${ }^{\mathrm{a}}$, S. Banerjee ${ }^{\mathrm{b}}$, O. Catuneanu ${ }^{\mathrm{c}}$, S. Sarkar ${ }^{\mathrm{d}}$, A.J. Bumby ${ }^{\mathrm{a}}$ and M.N. Mtimkulua}

${ }^{a}$ Department of Geology, University of Pretoria, Pretoria 0002, South Africa

${ }^{b}$ Department of Earth Sciences, IIT Bombay, Powai, Mumbai-400076, India

${ }^{\mathrm{c}}$ Department of Earth and Atmospheric Sciences, 1-26 Earth Sciences Building, University of Alberta, Edmonton, Alberta, Canada T6G 2E3

${ }^{\mathrm{d}}$ Department of Geological Sciences, Jadavpur University, Kolkata-700032, India

\section{Abstract}

Although the principle of uniformitarianism may be applied to the Precambrian sedimentary record as a whole, certain periods of the Archaean and Palaeoproterozoic witnessed a changing pattern of prime influences controlling the depositional systems. This paper examines the major controls on sedimentation systems and environments during the Archaean and Palaeoproterozoic within the broader perspective of Earth evolution. Earth's earliest sedimentary system (4.4?-3.7 Ga) was presumably comprised of deep oceanic realms and probably influenced primarily by bolide impacts, major tsunamis, localized traction and global contour current patterns, and bathymetry. As continental crust began to form, the impact-dominated, tsunami type sedimentation gave way to wider varieties of sedimentary environments, known from the oldest sedimentary records. During early continental crustal evolution (c. 3.7-2.7 Ga), sedimentation was essentially of greenstone-type. Volcanic and volcaniclastic rocks were the major components of the greenstone belts, associated with thin carbonates, stromatolitic evaporites, BIF, pelites and quartzites and lesser synorogenic turbidites, conglomerates and sandstones. Volcanism and active tectonism (reflecting dynamic depositional settings during island arc and proto-continental nucleus formation) were the predominant factors 
influencing sedimentation during this phase of Earth evolution. Transgressions and regressions under the combined influence of tectonics and eustasy are reflected in finingand coarsening-upwards successions from the proto-cratonic settings; low freeboard enabled the transgression to affect large areas of the proto-cratons. As the earliest, relatively stable craton formed, through a combination of plate tectonic and mantlethermal processes, continents and supercontinents with the potential for supercontinental cycles started to influence sedimentation strongly. Major controls on NeoarchaeanPalaeoproterozoic sedimentation systems $(2.7-1.6 \mathrm{Ga})$ were provided by a combination of superplume events and plate tectonics. Two global-scale 'superevents' at c. $2.7 \mathrm{Ga}$ and c. 2.2-1.8 Ga were accompanied by eustatic rise concomitant with peaks in crustal growth rates, and large epeiric seas developed. The operation of first-order controls leading to development of vast chemical sedimentary platforms in these epeiric seas and concomitant palaeo-atmospheric and palaeo-oceanic evolution combined to provide a second-order control on global sedimentary systems in the NeoarchaeanPalaeoproterozoic period. The supercontinental cycle had become well established by the end of the Palaeoproterozoic, with the existence of large cratons across broad spectrums of palaeolatitude enabling erg development. The entire spectrum of sedimentary systems and environments came into existence by c. $1.8 \mathrm{Ga}$, prime influences on sedimentation and depositional system possibly remaining essentially uniform thereafter.

\section{Article Outline}

1. Introduction

2. Controls on Earth's earliest sedimentary environments: the "magma ocean" and the "global ocean" stages (c. 4.4 (?) Ga-3.7 Ga)

3. Controls on sedimentation during greenstone belt and early continental crustal evolution (c. 3.7-2.7 Ga)

4. Controls on Neoarchaean-Palaeoproterozoic sedimentation (c. 2.7-c. 1.6 Ga)

5. Conclusion

Acknowledgements

References 


\section{Introduction}

It is well established that a uniform set of primary and secondary controls on sedimentary basin evolution, respectively the interaction of plate tectonic and mantle-thermal processes, modified by the influence of eustasy and palaeoclimate, have controlled the genetic history of depositories of all ages (e.g., [Eriksson et al., 2001a], [Eriksson et al., 2001b], [Eriksson et al., 2004a], [Eriksson et al., 2004b], [Eriksson et al., 2004c] and [Eriksson et al., 2005]). Eriksson et al. (1998) summarize differences between Precambrian depositional environments and their younger, better preserved and thus more intensively studied equivalents, but stress that the degree of similarity between older and younger examples greatly outweighs their differences. The first important principle of Precambrian sedimentation patterns is thus that Precambrian sedimentary lithologies, their contained structures and their inferred genesis almost all have modern counterparts (e.g., Altermann and Corcoran, 2002). The second important principle qualifies this statement: the major difference in Precambrian sedimentary settings lay in the variability of rates and intensities of processes (including those controlling weathering, erosion, transport, deposition, and diagenesis; e.g., [Donaldson et al., 2002], [Eriksson et al., 2004a] and [Eriksson et al., 2004d]), rather than the processes themselves. An important point when examining the sedimentary record on Earth is that it is strongly biased towards deposits laid down on stable continental platforms, and to the effective exclusion of the vast majority of the deposits formed in active tectonic settings, deep water environments and on thin oceanic crust.

Blind obeisance to application of the plate tectonic paradigm in Phanerozoic form during the earlier part of the Precambrian era has resulted in a widely accepted view that this hotter Earth was subject to enhanced rates of plate movement, as well as greatly increased lengths of constructive and destructive plate margins (e.g., De Wit, 1998). However, examination of Precambrian basin history suggests that the Archaean and Palaeoproterozoic may have been characterised by variable rather than universally higher rates of plate movement (e.g., Catuneanu, 2001; see discussion in Eriksson and Catuneanu, 2004). Concomitantly, low angle, shallow subduction may have been important at times (Cousens et al., 2004), and this led to unique basin evolutionary 
conditions for Earth's oldest preserved basin, the Witwatersrand of the Kaapvaal craton, South Africa ([Catuneanu, 2001] and [Eriksson and Catuneanu, 2004]). Catuneanu (2001) points out that the forebulge of this retro-arc flexural foreland basin remained emergent throughout its history, due to shallowly inclined subduction. Other important Precambrian variable rates affecting sedimentation included continental crustal growth rates (e.g., Arndt, 2004), a gradually decreasing rotation rate for the Earth (Williams, 2004a) and the evolution of the planet's hydrosphere-atmosphere system (Ohmoto, 2004).

However, despite the broad application of modern uniformitarianism to the Precambrian sedimentary record (cf. Donaldson et al., 2002), there is significant temporal control for several depositional environments: ancient ergs (aeolian sand seas) do not predate c. 2.01.8 Ga globally ([Eriksson and Simpson, 1998] and [Simpson et al., 2004a]); global-scale (Precambrian) glaciation is apparently restricted to the c. 2.4-2.2 event and several in the Neoproterozoic (e.g., [Young, 2004] and [Williams, 2004b]). Iron formations (and cherts) are essentially a unique Precambrian rock type, also strongly temporally influenced, with a peak in development at c. $2.5 \mathrm{Ga}$ and then decreasing in abundance until about $1.8 \mathrm{Ga}$, with a small peak in the Neoproterozoic (Trendall and Blockley, 2004). Biological influences were both reduced and enhanced in the Precambrian. Bioturbation was absent until the late Neoproterozoic (e.g., Eriksson et al., 2001b) and preservation of delicate structures is thus often achieved. In contrast, microbial mats flourished in the absence of grazing invertebrates in the Precambrian, and these mats colonised shallow marine and even terrestrial environments to a significant degree (e.g., [Schieber, 1998], [Schieber, 2004] and [Eriksson et al., 2000]); their presence often enhanced resistance to erosion and they also provided cohesion to clastic sediments (Fig. 1), and thereby even affected preserved sequence architecture ([Sarkar et al., 2005] and [Banerjee and Jeevankumar, 2005]). 


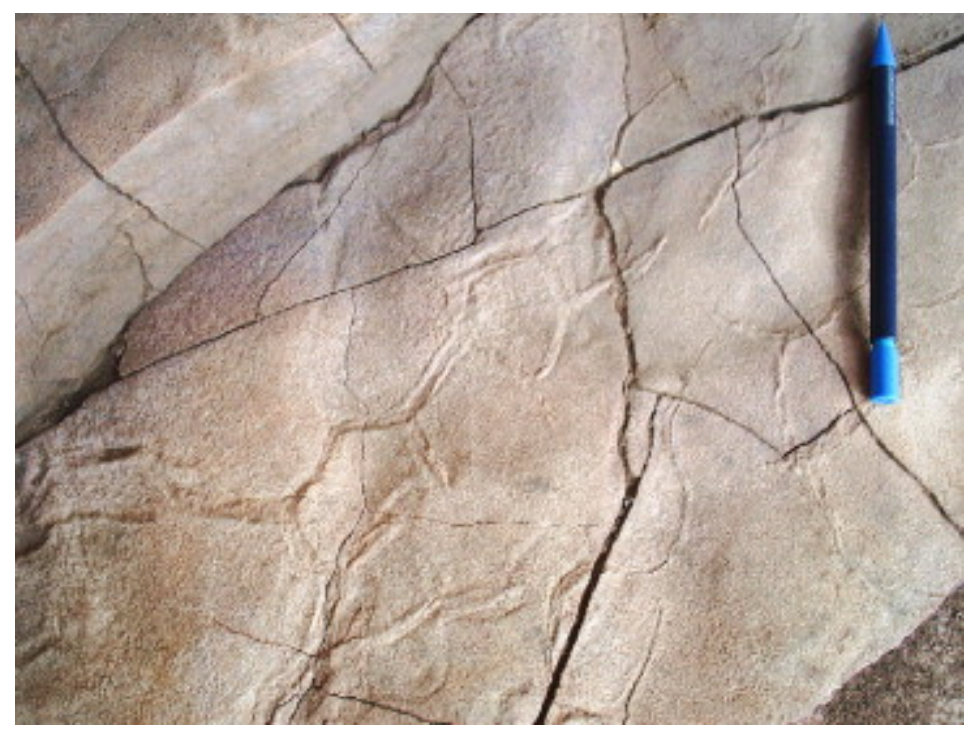

Fig. 1. Sand cracks preserved in c. $1.8 \mathrm{Ga}$ sandstones of the Waterberg Group, South Africa. Note overlying sandstone bed succeeding that with the cracks, without the presence of an intervening mudrock bed. Cohesion can thus be inferred to have been provided to the lower sandy bed (to form cracks) by a microbial mat. Pen for scale. Photo: courtesy of Igor Tonzetic. (cracks) by a microbial mat. Pen for scale. Photo: courtesy of Igor Tonzetic.

\section{Controls on Earth's earliest sedimentary}

\section{environments: the "magma ocean" and the "global ocean” stages (c. 4.4 (?) Ga-3.7 Ga)}

After formation of the solar system by c. 4570 Ma, a "magma ocean" stage in early Earth history is thought to have persisted for several hundred million years ([Delsemme, 1995] and [Nelson, 2004]). A combination of continually recycled komatiitic-basaltic protocrusts, a chaotically convecting and partially mobile mantle subject to overturn events, all combined with major bolide impacts characterised this early Earth phase ([Mukhin and Pinenov, 2002], [Nelson, 1998] and [Nelson, 2004]). Sedimentation would have begun on this early, inhospitable Earth, probably characterised largely by variable-calibre volcaniclastic detritus transported mainly by gravity and possibly aeolian movement of 
finer particles, with weak weathering under a largely steam atmosphere (Eriksson et al., 2005). Preservation potential of volcaniclastic and possible aeolian deposits would have been minimal due to the mantle recycling of transient basaltic crust. Most of the water from c. 4.57 to about $4.0 \mathrm{Ga}$ was presumably in the form of steam in the atmosphere and sedimentation due to the hydrological cycle would thus, apparently have been impossible then. Wilde et al. (2001) and Mojzsis et al. (2001) use high $\delta^{18} \mathrm{O}$ values from the oldest known zircon grains (c. 4400-4000 Ma) to argue in favour of liquid water on Earth's surface at $4404 \mathrm{Ma}$; however these elevated values possibly also reflect a secondary origin and most researchers reject this concept of a "cool early Earth" (Nelson, 2004 and discussions therein). Mechanical sediment formation and transport would have predominated with the main control being bolide impacts on transient "oceanic" crust, combined with gravity-flows.

The next step in Earth's evolution, the transition from this chaotic whole mantle convection to a layered mantle, the formation of the earliest continental crust, the onset of the plate tectonic regime, and the condensation of volcanic gases to form primitive atmosphere and the hydrosphere, is one fraught with debate. Postulates vary from shallow subduction of thick and hot oceanic lithosphere ("subduction and slab-melt model"; e.g., Martin and Moyen, 2002), through intra-oceanic obduction (e.g., [De Wit, 1991] and [De Wit, 1998]), in-situ crustal differentiation and delamination (cf. ocean plateaus; e.g., Zegers and Van Keken, 2001) to Trendall's (2002) "plughole" model (see Eriksson and Catuneanu, 2004 for detailed discussion). All these models require at least partial global ocean development (cf. De Wit and Hynes, 1995) with concomitant subaqueous primitive "oceanic" (komatiitic) crust. Equally effusive debate surrounds the timing of this transition (e.g., references and discussions in [Eriksson et al., 2004a], [Eriksson et al., 2005] and [Eriksson and Catuneanu, 2004]).

Once ocean evolution had begun (apparently by at least $3.7 \mathrm{Ga}$, and possibly as early as c. $4.4 \mathrm{Ga}$ according to the "cool early Earth" school of thought, cf. Wilde et al., 2001 and Mojzsis et al., 2001; Eriksson et al., 2005), the formation of proto-cratonic nuclei would presumably have followed. Prior to the emergence of the earliest continental crust from 
the global ocean (i.e. the onset of positive freeboard) and assuming c. $>90 \%$ of modern oceanic volumes by approximately $4.0 \mathrm{Ga}$ (Condie, 1997), an oceanic sedimentary realm would have dominated on Earth. Initially, water depths would have been mainly abyssal, but development of continental crust would in time have led to the full possible bathymetric range of marine environments. This initially relatively deep oceanic realm would likely have been geographically pervasive, and was still subject to bolide impacts (with an estimated 15 times the present rate at c. $3.8 \mathrm{Ga}$; Ryder, 2003). In the absence of biochemical planktonic sedimentation (e.g., Altermann, 2004) and terrestrial loessic sedimentation, such catastrophic events dominated the "global ocean", targeting subaqueous high Mg-basalts and komatiites.

Enormous tsunamis would have been common and as continental crust developed, would have resulted in tidal waves forming large, ripped-up blocks and major unconformities (Eriksson et al., 2005); widespread deposition of cataclastic mafic volcanic debris, reworked by marine (including contour) currents, cross-bedding (Hassler and Simonson, 2001) resulting from impact generated traction currents, anti-dune cross-bedding ([Bretz, 1969] and [Abbott and Hagstrum, 2004]), and turbidites where the requisite palaeoslopes existed, would have been common. The major controls on sedimentation in this phase of Earth's evolution would presumably thus have been bolide impacts, localized traction and global contour current patterns, and bathymetry. However, due to the destruction of ocean floor (ophiolites excluded) older than Jurassic age, remnants of this earliest global sedimentary pattern have not been preserved in the rock record. As continental crustal genesis began to take hold, the period of impact-dominated, tsunami-type sedimentation would have graded into the much more complete range of sedimentary environments known from the earliest preserved Precambrian sedimentation record.

\section{Controls on sedimentation during greenstone belt and early continental crustal evolution (c. 3.7-2.7 Ga)}

Continental crust older than c. 3.0 Ga probably formed by several processes, such as mantle plumes and concomitant oceanic plateaux, intra-oceanic accretionary complexes 
(implying plate tectonism) and, most likely prior to these, by processes inherent in Trendall's (2002) plughole model ([De Wit and Hynes, 1995] and [Eriksson and Catuneanu, 2004] and references therein). Most workers would agree that modern-style plate tectonics was applicable in the Neoarchaean; however, the timing of the change from an earlier regime with a chaotically convecting mantle to the layered mantle implicit in the plate tectonic paradigm remains speculative (e.g., [Trendall, 2002] and [Eriksson and Catuneanu, 2004]). The resultant continental crust reached c. $20 \%$ of present volumes by approximately $3.0 \mathrm{Ga}$ and about $80 \%$ by the end of the Archaean ([Cogley, 1984] and [Taylor and McLennan, 1985]). These continental realms comprised a combination of small (but growing) cratons (formed by intra-oceanic island arc and oceanic plateau collisions; cf. Windley, 1995) within predominant oceanic settings, and sedimentation patterns were essentially those of greenstone-type, which continued until about $2.7 \mathrm{Ga}$; thereafter profound changes occurred in Earth's evolution (Eriksson et al., 2004a) (Fig. 1).

These greenstone belts, possibly as old as 4.0 Ga (De Wit and Hynes, 1995), were characterised by komatiitic, tholeiitic and felsic volcanic and volcaniclastic rocks (e.g., Fedo et al., 2001). The volcanic settings were associated with thin successions of carbonates, BIF, stromatolitic evaporites, pelites and quartzarenites, developed on limited passive margins to active volcanic island chains, with subordinate preserved deposits of synorogenic turbidites, conglomerates and sandstones (Windley, 1995). These synorogenic volcano-sedimentary greenstone successions generally exhibit subaerial and subaqueous sedimentary rocks interbedded with volcanic and volcaniclastic beds ([Barrett and Fralick, 1989], [DiMarco and Lowe, 1989], [Eriksson et al., 1994] and [Mueller and Corcoran, 2001]).

Chemical sedimentation, although limited in volume, was already active and highly variable. Within the shallow marine environments flanking proto-continental nuclei and small cratons, microbial mats would have trapped and bound sediment to form small carbonate platforms (e.g., [Wright and Altermann, 2000], [Schopf, 2004] and [Kazmierczak et al., 2004]), and carbonate may even have precipitated directly from 
seawater according to Grotzinger (1989). Archaean seawater was probably enriched in iron derived from fumaroles, and sulphidic iron formations developed beneath the pycnocline (Veizer, 1983), with their oxidic equivalents above, where photosynthesis could function (Eriksson et al., 1997). The Archaean equivalent of the pelagic "rain-out" of starved basin muds was probably provided by such iron minerals, in the absence of planktonically derived sediment particles (Eriksson, 1983). Gypsum deposits from this era occur and are ascribed either to a seawater evaporate genesis ([Lowe, 1983] and [Buick and Dunlop, 1990]) or to an origin from sites of continental runoff (Grotzinger and Kasting, 1993).

Active tectonism in these dynamic island arc-emerging proto-craton-greenstone settings was a predominant influence on sedimentation during this era of Earth evolution (e.g., [Ingersoll, 1988] and [Eriksson and Fedo, 1994]). Corcoran and Mueller (2004) indicate three important types of succession: craton-cover (both synrift and stable platform sequences), synorogenic and molasse successions. Reviews of Archaean lithofacies (Eriksson et al., 1994), clastic sedimentation patterns (Ojakangas, 1985) and greenstone sedimentation in general ([Lowe, 1994] and [Eriksson et al., 1997]) indicate that highgradient alluvial fans, low sinuosity braided rivers, shallow marine settings subject to wave and tidal action, turbidity currents and storm deposition on narrow shelves were important aspects of deposition. Transgressions and regressions under the combined influences of tectonism and eustasy are reflected in fining- and coarsening-upwards successions from proto-cratonic settings, with BIF topping clastic deposits indicating drowning of clastic craton-cover and shelf successions ([Fedo and Eriksson, 1996] and [Corcoran and Mueller, 2004]). The Archaean marine sedimentary record is dominated by shallow marine settings ([Windley, 1995] and [Eriksson et al., 1997]) due to an absence of preserved ocean floor, possible ophiolites (e.g., Chiarenzelli and Moores, 2004) excepted.

One of the major controls on Archaean sedimentation thus appears to have been active tectonism, reflecting the dynamic depositional settings during island arc and protocontinental nucleus formation. A second important control on Archaean sedimentation 
patterns was volcanism. The role of volcanism is especially noted within the ancient alluvial systems in greenstones: lava flows produced a dynamic palaeotopography which affected alluvial sediment dispersal systems, and the predominant braided channel systems (cf. Long, 2004) became congested with volcaniclastic debris, promoting hyperconcentrated flood- and debris-flow deposits ([Mueller and Corcoran, 1998] and [Corcoran and Mueller, 2004]). Immature terrestrial molasse successions within greenstone settings, formed within high-relief, fault-bounded basins, with deposition in fans, fan-deltas and braidplains with small lakes, prograded directly onto shallow shelf settings, where significant tides reflecting reduced mean Earth-Moon distance (Mueller et al., 2002; see, however, Williams, 2004a) reworked them (e.g., [Krapez and Barley, 1987], [Mueller and Corcoran, 1998], [Corcoran et al., 1998] and [Corcoran et al., 1999]).

As the earliest, small, relatively stable craton (Kaapvaal, South Africa) emerged from a combination of Mesoarchaean plate tectonism and concomitant mantle thermal processes (e.g., Eriksson et al., 2002), a subtle yet very significant shift began in the influences on Precambrian sedimentation: continents and supercontinents, and the potential for operation of the supercontinent cycle. This change began on a global scale only in the latest Neoarchaean and succeeding Palaeoproterozoic, as discussed in the next section. The epeiric marine Witwatersrand-Pongola basin (c. 3.1-2.7 Ga) of Kaapvaal stands in stark contrast to the typical greenstone depositories then prevalent on Earth, such as the 2.94 Ga Mallina basin, Pilbara (the second oldest craton, as yet incomplete and largely unstable) (e.g., Smithies et al., 2001). In contrast to the earliest partly stable cratons, Kaapvaal and Pilbara, continental growth until c. 2.7 Ga occurred largely through continued greenstone belt evolution, e.g., in the Slave Province, northern Canada (Mueller and Corcoran, 2001) or on the Zimbabwe craton (Hofmann et al., 2001). The retro-arc foreland basin model interpreted for the thick fluvial and littoral deposits of the greater Witwatersrand basin (e.g., Catuneanu, 2001) encompasses an inferred small flexural wavelength for the foreland system, attributed to the young (newly cratonised), and hence less rigid, underlying lithosphere. Catuneanu (2001) suggests that the lack of forebulge sedimentation may be typical for earlier Precambrian retro-arc foreland 
systems due to lower rates of subduction, and hence absence of dynamic loading, as the plate tectonic system became fully established on Earth (Eriksson et al., 2005). Low freeboard (Eriksson et al., 2006) enabled transgression of the Witwatersrand epeiric sea for at least $400 \mathrm{~km}$ onto the Kaapvaal craton (Eriksson et al., 1998). The Witwatersrand basin can, however, still be seen as transitional from greenstone settings, as it shares a somewhat analogous character with greenstone depositories: compressional tectonic setting; influence of granite batholiths; vertical stratigraphic transition from volcanic rocks to deep water to shallow water sedimentary lithologies (Eriksson et al., 2001b). The Pongola Supergroup, which formed the seaward, higher energy portion of the greater Witwatersrand basin (e.g., Beukes and Cairncross, 1991) preserved the oldest known large carbonate platform, albeit within a predominantly siliciclastic-volcanic succession; the Pongola microbial communities were thus the first to form large bioherms thereby influencing local architecture within a sedimentary basin ([Walter, 1983] and [Altermann, 2004]). Although bacterial life apparently flourished within greenstone settings, life only began to influence sedimentation patterns significantly with the onset of the earliest cratonic basin. The Witwatersrand basin-fill also contains ventifacts, indicating localized aeolian erosional processes (Els, 1998).

\section{Controls on Neoarchaean-Palaeoproterozoic sedimentation (c. 2.7-c. 1.6 Ga)}

Models for continental crustal growth rates, varying from those emphasising episodicity (e.g., [Taylor and McLennan, 1985], [McLennan and Taylor, 1991] and [Condie, 1998]) to those emphasising early generation followed by recycling into the mantle (e.g., Armstrong, 1991) aside, there appears to have been a major peak in crustal generation at c. $2.7 \mathrm{Ga}$ (e.g., Arndt, 2004). From at least the Neoarchaean, an interplay of plate tectonics and thermal processes (cf. mantle (super)plumes [see Condie, 2004 and Ernst et al., 2004, for different definitions] and their products, large igneous provinces, or "LIP's") provided the first-order control on Earth evolution (e.g., Eriksson et al., 2001b, 2004e; Eriksson and Catuneanu, 2004). Condie (2004) defines a "superplume event" (SPE), a global-scale chronologically restricted assemblage of superplumes and 
speculates that an initial catastrophic slab avalanche event at c. $2.7 \mathrm{Ga}$ under a by-thenpredominant plate tectonic system on Earth, may have triggered the first SPE at this time (e.g., [Peltier et al., 1997] and [Condie, 1998]). The transition, at c. $2.7 \mathrm{Ga}$, to a fully plate tectonic Earth appears to have been accompanied by a global-scale catastrophic mantle overturn event and the generation of voluminous granite-greenstone crust on the Yilgarn and Superior cratons, at 2760-2620 Ma, including a major, possibly global-scale 2705 Ma komatiite eruptive event ([Nelson, 1998] and [Nelson, 2004]).

A first-order control on Neoarchaean-Palaeoproterozoic sedimentation was thus provided by the combination of plumes and plate tectonics. Although this is analogous to that proposed in the previous section, a major difference from c. $2.7 \mathrm{Ga}$ onwards was the presence of larger and more stable cratonic plates and a fully developed plate tectonic regime (although one subject to variable rather than universally higher velocities - see [Catuneanu, 2001], [Eriksson and Catuneanu, 2004], [Catuneanu et al., 2004] and [Catuneanu et al., 2005]), enabling formation of the earliest supercontinent (c. $2.7 \mathrm{Ga}$ "Kenorland"; Aspler and Chiarenzelli, 1998) and the first Himalayan-style mobile belts: the Limpopo (however, age subject to debate: c. 2.7 or c. $2.0 \mathrm{Ga}$ ) and the Hoggar, both in Africa. The former has evidence for possible ophiolites (Bumby and van der Merwe, 2004; age debate also discussed).

An inferred association of a SPE with Kenorland breakup led to globally elevated sea levels, peaks in stromatolite diversity and occurrence, and important changes in ocean chemistry (e.g., [Condie, 2004] and [Ohmoto, 2004]). Where plumes impinged directly beneath cratonic terranes (e.g., Kaapvaal: $2.7 \mathrm{Ga}$ Ventersdorp continental flood basalts erupted under high freeboard) or close to them (e.g., the coeval Fortescue flood basalts, Pilbara craton, lower freeboard; Eriksson et al., 2006) eustatic rise was locally reversed to relative sea-level fall on individual plates (e.g., Eriksson et al., 2002). A second combination of analogous global-scale dynamic events (cf. global "superevent" in Eriksson et al., 2004a), at c. 2.2-1.8 Ga (Fig. 2), encompassed a peak in greenstone belt volcanism, probably two supercontinents, an SPE, an ophiolite complex cluster as well as local peaks in continental crustal growth (Eriksson et al., 2004e). Again, significant 
biochemical events were recorded within the atmosphere and hydrosphere (e.g., [Ohmoto, 2004] and [Eriksson et al., 2004a]; Fig. 2). 


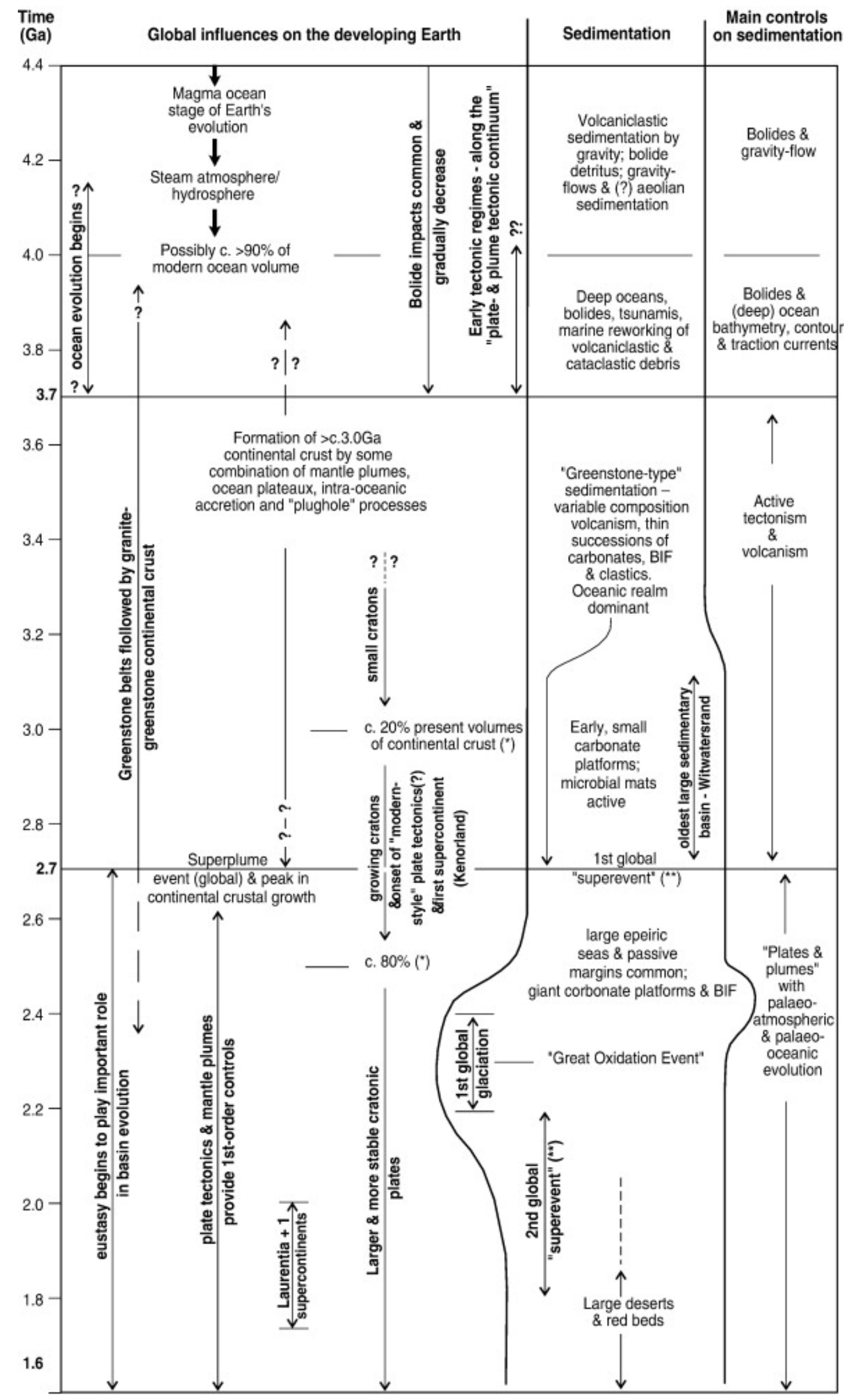


Fig. 2. Schematic summary time chart, showing main influences on Earth evolution and sedimentation from c. 4.4 Ga to 1.6 Ga. Modified after Eriksson et al. (2004e). Between the c. 2.7 and 2.2-1.8 Ga "superevents", a measure of global-scale tectonic quiescence prevailed, accompanied by eustatic rise concomitant with the crustal growth peak at c. $2.7 \mathrm{Ga}$. As a result, from c. 2.6 to $2.4 \mathrm{Ga}$, large epeiric seas occupied passive margin basins on many of the Kenorland daughter fragments during this interlude (e.g., [Eriksson and Martins-Neto, 2004], [Eriksson et al., 2004b] and [Eriksson et al., 2004c]). The first giant carbonate platforms developed in these epicontinental seas (Kaapvaal and Pilbara cratons), and iron formations (IF) formed a significant element in these and many other epeiric basins, with a global peak in development at c. $2.5 \mathrm{Ga}$ (Trendall and Blockley, 2004). The great similarity in structural and sedimentary settings, sedimentation rates, textural and mineralogical characteristics of Precambrian and modern carbonate rocks, suggests analogous microbiotic and calcification processes ([Nelson et al., 1999], [Altermann, 2004] and [Kazmierczak et al., 2004]). Many of these epeiric basins also hosted thick successions of clastic detritus (e.g., Eriksson et al., 2006). The operation of the first-order control alluded to above thus led to a combination of common epeiric seas, vast chemical sedimentary platforms and concomitant palaeoatmospheric and palaeo-oceanic evolution, which combined to provide an important second-order control on global sedimentary systems in the NeoarchaeanPalaeoproterozoic period.

Iron formation, an essentially Precambrian sedimentary rock type, has a known history from its earliest examples at c. $3.8 \mathrm{Ga}$, followed by poorly developed younger Archaean occurrences generally associated with greenstone belt volcanism; the c. 2.5 Ga IF peak was succeeded by common granular IF at c. $1.8 \mathrm{Ga}$, and a long hiatus preceding local development of the Neoproterozoic IFs (Trendall and Blockley, 2004). These authors apply an iron- and Eh-stratified ocean model to IF evolution, with deep, iron-rich waters ([Holland, 1973] and [Holland, 1984]) upwelled onto shallow shelf settings of the common epeiric basins (Klein and Beukes, 1989), or where a pycnocline was close to the level of such basin floors. Trendall and Blockley (2004) thus dispute using IFs as a proxy 
for atmospheric oxygen content, and ascribe the lack of significant Mesoproterozoic IFs to increasing oceanic oxygen as photosynthetic organisms became more prevalent, within their stratified ocean model. The c. 2.3 Ga "Great Oxidation Event" (Karhu and Holland, 1996), generally attributed to significant burial of organic carbon (thus increasing atmospheric $\mathrm{O}_{2}$ ) is related by many other workers to the global (Banded)IF depositional peak, the global 2.3-2.2 Ga carbon isotopic excursion and the Palaeoproterozoic glaciation event (e.g., Lindsay and Brasier, 2004). Two essentially mutually exclusive models of palaeo-atmospheric and -oceanic evolution exist (both based upon the same, largely equivocal dataset; Ohmoto, 2004): (1) that the "faint young Sun" was countered by biogenic methane as the main greenhouse gas; a major $\mathrm{O}_{2}$ rise at c. $2.0 \mathrm{Ga}$; anoxic oceans (excluding the photic zone) until c. $0.6 \mathrm{Ga}$; and an inferred stepwise increase in $\mathrm{SO}_{4}{ }^{-}$contents at c. $2.2 \mathrm{Ga}$ and $0.8 \mathrm{Ga}$ (e.g., [Cloud, 1968], [Walker, 1977], [Holland, 2002], [Kasting and Siefert, 2002] and [Lyons et al., 2004]); (2) oxygenic photosynthesis soon after differentiation of oceanic and continental crust at c. $4 \mathrm{Ga}$ and a rise in atmospheric $\mathrm{O}_{2}$ shortly thereafter; oxygenated oceans with essentially constant $\mathrm{SO}_{4}{ }^{-}$ levels since c. $4.0 \mathrm{Ga} ; \mathrm{CO}_{2}$ as the main greenhouse gas (e.g., [Dimroth and Kimberley, 1976], [Lasaga and Ohmoto, 2002] and [Ohmoto, 2004]).

Palaeoclimatic change consequent upon palaeo-atmospheric evolution was another characteristic of the Palaeoproterozoic. Following earlier isolated mountain-glacier deposits ([Page, 1981] and [Von Brunn and Gold, 1993]), the first global-scale glaciation occurred at c. 2.4-2.2 Ga (e.g., [Young, 1991], [Young, 2002] and [Young, 2004]). Their lack of temporal relationships with BIF or cap carbonates lends little support ([Williams, 2004b] and [Young, 2004]) for the "snowball Earth" hypothesis (e.g., [Kirschvink, 1992] and [Hoffman et al., 1998]; see, however, Eyles and Januszczak, 2004). Global carbon isotope curves, generally flat for much of the Precambrian, exhibit a major oscillatory excursion at c. 2.3-2.2 Ga, which has been interpreted as reflecting the supercontinent cycle more than major palaeo-atmospheric compositional changes ([Lindsay and Brasier, 2002], [Lindsay and Brasier, 2004] and [Brasier et al., 2002]). The large obliquity hypothesis ([Williams, 1975], [Williams, 1993] and [Williams, 2004b]), while explaining 
the distribution and nature of pre-Ediacaran Precambrian glacial palaeoenvironments, is independent of possible causes of global refrigeration.

Following formation of supercontinent "Laurentia" at c. $2.0-1.7 \mathrm{Ga}$ and an approximately coeval "southern" (in modern reference frame) equivalent by c. $1.8 \mathrm{Ga}$, large land masses enabled erg formation (Fig. 3) for the first time, on many of the preserved cratons (e.g., [Eriksson and Simpson, 1998], [Eriksson et al., 2000], [Simpson et al., 2004a] and [Simpson et al., 2004b]). Concomitantly, red beds sensu stricto became common in many successions (e.g., Eriksson and Cheney, 1992), indicating the unequivocal presence of free oxygen in the atmosphere by that time. As the Palaeoproterozoic ended, the supercontinental cycle had become well developed, and with it the sedimentary systems that accompany the Wilson cycle (e.g., [Hoffman, 1989], [Barley and Groves, 1992] and [Windley, 1995]). With the addition of deserts from about c. 1.8 Ga globally, all the principle sedimentary systems and environments were present on Earth, with the apparent exception of glaciation, which remained strongly episodic (Eriksson et al., 2005).

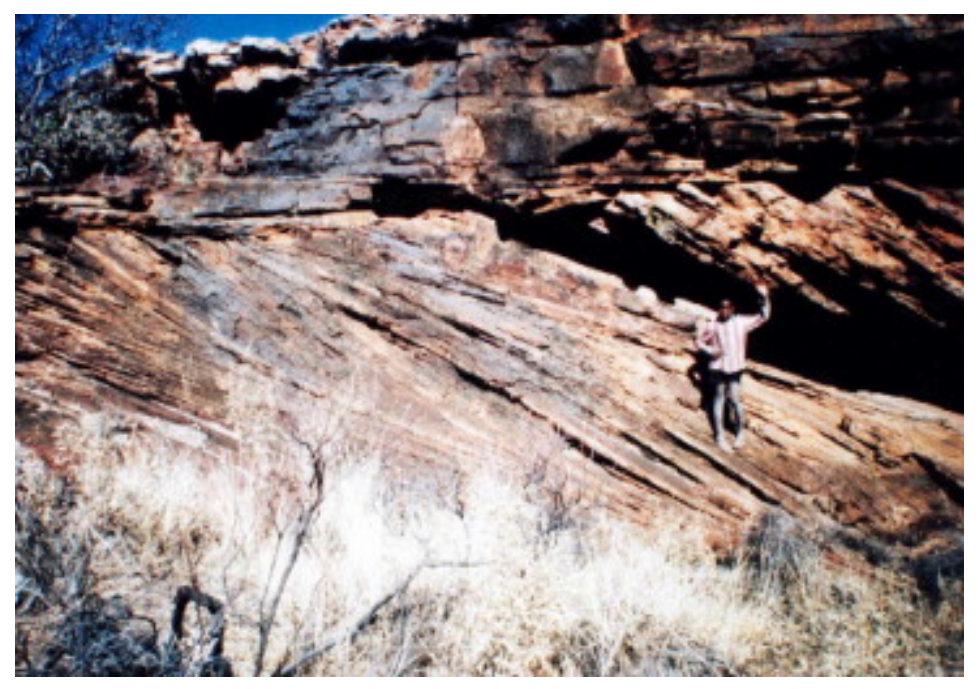

Fig. 3. Several sets of large scale aeolian cross-bedding within the c. 1.8 Ga Makgabeng Formation, Waterberg Group, South Africa. These occur within one of several ergs developed on Earth at this approximate time period in the earliest deserts. Child for scale. 


\section{Conclusion}

Although there appears to have been a very significant order of uniformitarianism in the myriad and interacting large- and small-scale controls on sedimentation throughout Earth history (e.g., [Eriksson et al., 1998], [Eriksson et al., 2004a], [Eriksson et al., 2004d] and [Eriksson et al., 2004e]), certain periods during the Archaean-Palaeoproterozoic probably were subject to a changing pattern of prime influences controlling evolution and preservation of the sedimentary record (Fig. 2):

(1) c. 4.4 (?)-3.7 Ga: bolide impacts and associated tsunamis, localized traction and global contour currents, and bathymetry;

(2) c. 3.7-2.7 Ga: active tectonism (dynamic depositional settings during island arc and proto-continental nucleus formation) and volcanism;

(3) c. 2.7-1.6 Ga: common epeiric seas, vast chemical sedimentary platforms (biological influences) and concomitant palaeo-atmospheric and palaeo-oceanic evolution.

\section{References}

Abbott and Hagstrum, 2004 D.H. Abbott and J.T. Hagstrum, Strategies for finding the record of early Precambrian impact events. In: P.G. Eriksson, W. Altermann, D.R. Nelson, W.U. Mueller and O. Catuneanu, Editors, The Precambrian Earth: Tempos and Events, Elsevier, Amsterdam (2004), pp. 45-62.

Altermann, 2004 W. Altermann, Precambrian stromatolites: problems in definition, classification, morphology and stratigraphy. In: P.G. Eriksson, W. Altermann, D.R. Nelson, W.U. Mueller and O. Catuneanu, Editors, The Precambrian Earth: Tempos and Events, Elsevier, Amsterdam (2004), pp. 564-574.

Altermann and Corcoran, 2002 In: W. Altermann and P.L. Corcoran, Editors, Precambrian Sedimentary Environments: A Modern Approach to Ancient Depositional Systems, I.A.S. Spec. Publ. vol. 33, Blackwell, Oxford (2002) 450 pp..

Arndt, 2004 N.T. Arndt, Crustal growth rates. In: P.G. Eriksson, W. Altermann, D.R. Nelson, W.U. Mueller and O. Catuneanu, Editors, The Precambrian Earth: Tempos and Events, Elsevier, Amsterdam (2004), pp. 155-158. 
Armstrong, 1991 R.L. Armstrong, The persistent myth of crustal growth, Aust. J. Earth Sci. 38 (1991), pp. 613-630.

Aspler and Chiarenzelli, 1998 L.B. Aspler and J.R. Chiarenzelli, Two Neoarchean supercontinents? Evidence from the Paleoproterozoic, Sediment. Geol. 120 (1998), pp. $75-104$.

Banerjee and Jeevankumar, 2005 S. Banerjee and S. Jeevankumar, Microbial mat response to physical process generating varied forms of wrinkle marks in sand: evidences from Mesoproterozoic Koldaha Shale, central India, Sediment. Geol. 176 (2005), pp. 211-224.

Barley and Groves, 1992 M.E. Barley and D.I. Groves, Supercontinent cycles and the distribution of metal deposits through time, Geology 20 (1992), pp. 291-294.

Barrett and Fralick, 1989 T.J. Barrett and P.W. Fralick, Turbidites and iron-formations, Beardmore-Geraldton, Ontario: application of a combined ramp/fan model to Archaean clastic and chemical sedimentation, Sedimentology 36 (1989), pp. 221-234.

Beukes and Cairncross, 1991 N.J. Beukes and B. Cairncross, A lithostratigraphicsedimentological reference profile for the Late Archaean Mozaan Group, Pongola Sequence: application to sequence stratigraphy and correlation with the Witwatersrand Supergroup, S. Afr. J. Geol. 94 (1991), pp. 44-69.

Brasier et al., 2002 M.D. Brasier, O.R. Green, A.P. Jephcoat, A.K. Kleppe, M.J. Van Kranendonk, J.F. Lindsay, A. Steele and N.V. Grassineau, Questioning the evidence for Earth's oldest fossils, Nature 416 (2002), pp. 76-81.

Bretz, 1969 J.H. Bretz, The lake missoula floods and the channeled scabland, J. Geol. 77 (1969), pp. 505-543. 
Buick and Dunlop, 1990 R. Buick and J.S.R. Dunlop, Evaporitic sediments of Early Archaean age from the Warrawoona Group, North Pole, Western Australia, Sedimentology 37 (1990), pp. 247-277.

Bumby and van der Merwe, 2004 A.J. Bumby and R. van der Merwe, The Limpopo Belt of southern Africa: a Neoarchaean to Palaeoproterozoic orogen. In: P.G. Eriksson, W. Altermann, D.R. Nelson, W.U. Mueller and O. Catuneanu, Editors, The Precambrian Earth: Tempos and Events, Elsevier, Amsterdam (2004), pp. 217-222.

Catuneanu, 2001 O. Catuneanu, Flexural partitioning of the Late Archaean Witwatersrand foreland system, South Africa, Sediment. Geol. 141/142 (2001), pp. 95112.

Catuneanu et al., 2004 O. Catuneanu, A.F. Embry and P.G. Eriksson, Concepts of sequence stratigraphy. In: P.G. Eriksson, W. Altermann, D.R. Nelson, W.U. Mueller and O. Catuneanu, Editors, The Precambrian Earth: Tempos and Events, Elsevier, Amsterdam (2004), pp. 685-705.

Catuneanu et al., 2005 O. Catuneanu, M.A. Martins-Neto and P.G. Eriksson, Precambrian sequence stratigraphy, Sediment Geol. 176 (2005), pp. 67-95.

Chiarenzelli and Moores, 2004 J.R. Chiarenzelli and E.M. Moores, Precambrian ophiolites. In: P.G. Eriksson, W. Altermann, D.R. Nelson, W.U. Mueller and O. Catuneanu, Editors, The Precambrian Earth: Tempos and Events, Elsevier, Amsterdam (2004), pp. 213-217.

Cloud, 1968 P.E. Cloud, Atmospheric and hydrospheric evolution on the primitive earth, Science 160 (1968), pp. 729-736.

Cogley, 1984 J.G. Cogley, Continental margins and the extent and number of continents, Rev. Geophys. Space Phys. 22 (1984), pp. 101-122. 
Condie, 1997 K.C. Condie, Plate Tectonics and Crustal Evolution (4th ed.), Butterworth Heinemann, Oxford (1997) 282 pp..

Condie, 1998 K.C. Condie, Episodic continental growth and supercontinents: a mantle avalanche connection?, Earth Planet. Sci. Lett. 163 (1998), pp. 97-108.

Condie, 2004 K.C. Condie, Precambrian superplume events. In: P.G. Eriksson, W. Altermann, D.R. Nelson, W.U. Mueller and O. Catuneanu, Editors, The Precambrian Earth: Tempos and Events, Elsevier, Amsterdam (2004), pp. 163-173.

Corcoran and Mueller, 2004 P.L. Corcoran and W.U. Mueller, Archaean sedimentary sequences. In: P.G. Eriksson, W. Altermann, D.R. Nelson, W.U. Mueller and O. Catuneanu, Editors, The Precambrian Earth: Tempos and Events, Elsevier, Amsterdam (2004), pp. 613-625.

Corcoran et al., 1998 P.L. Corcoran, W.U. Mueller and E.H. Chown, Climatic and tectonic influences on fan deltas and wave- to tide-controlled shoreface deposits: evidence from the Archean Keskarrah Formation, Slave Province, Canada, Sediment. Geol. 120 (1998), pp. 125-152.

Corcoran et al., 1999 P.L. Corcoran, W.U. Mueller and W.A. Padgham, Influence of tectonism and climate on lithofacies distribution and sandstone and conglomerate composition in the Archean Beaulieu Rapids formation, Northwest Territories, Canada, Precambrian Res. 94 (1999), pp. 175-204.

Cousens et al., 2004 B.L. Cousens, J.R. Chiarenzelli and L.B. Aspler, An unusual Palaeoproterozoic magmatic event, the ultrapotassic Christopher Island Formation, Baker Lake Group, Nunavat, Canada: Archaean mantle metasomatism and Palaeoproterozoic mantle reactivation. In: P.G. Eriksson, W. Altermann, D.R. Nelson, W.U. Mueller and O. 
Catuneanu, Editors, The Precambrian Earth: Tempos and Events, Elsevier, Amsterdam (2004), pp. 183-201.

De Wit, 1991 M.J. De Wit, Archaean greenstone belt tectonism and basin development: some insights from the Barberton and Pietersburg greenstone belts, Kaapvaal Craton, South Africa, J. Afr. Earth Sci. 13 (1991), pp. 45-63.

De Wit, 1998 M.J. De Wit, On Archean granites, greenstones, cratons and tectonics: does the evidence demand a verdict?, Precambrian Res. 91 (1998), pp. 181-226.

De Wit and Hynes, 1995 M.J. De Wit and A. Hynes, The onset of interaction between the hydrosphere and oceanic crust, and the origin of the first continental lithosphere. In: M.P. Coward and A.C. Ries, Editors, Early Precambrian Processes, Spec. Publ. Geol. Soc. London vol. 95 (1995), pp. 1-9.

Delsemme, 1995 A.H. Delsemme, Cometary origin of the biosphere: a progress report, Adv. Space Res. 15 (1995), pp. (3)49-(3)57.

DiMarco and Lowe, 1989 M.J. DiMarco and D.R. Lowe, Stratigraphy and sedimentology of an Early Archean felsic volcanic sequence, Eastern Pilbara Block, Western Australia, with special reference to the Duffer Formation and implications for crustal evolution, Precambrian Res. 44 (1989), pp. 147-169.

Dimroth and Kimberley, 1976 E. Dimroth and M.M. Kimberley, Precambrian atmospheric oxygen: evidence in the sedimentary distributions of carbon, sulfur, uranium, and iron, Can. J. Earth Sci. 13 (1976), pp. 1161-1185.

Donaldson et al., 2002 J.A. Donaldson, P.G. Eriksson and W. Altermann, Actualistic versus non-actualistic conditions in the Precambrian: a reappraisal of an enduring discussion. In: W. Altermann and P.L. Corcoran, Editors, Precambrian Sedimentary 
Environments: A Modern Approach to Ancient Depositional Systems, I.A.S. Spec. Publ. vol. 33, Blackwell, Oxford (2002), pp. 3-13.

Els, 1998 B.G. Els, The auriferous Late Archaean sedimentation systems of South Africa: unique palaeoenvironmental conditions?, Sediment. Geol. 120 (1998), pp. 205-224.

Eriksson, 1983 K.A. Eriksson, Siliciclastic-hosted iron-formations in the early Archean Barberton and Pilbara sequences, J. Geol. Soc. Aust. 30 (1983), pp. 473-482.

Eriksson and Catuneanu, 2004 P.G. Eriksson and O. Catuneanu, A commentary on Precambrian plate tectonics. In: P.G. Eriksson, W. Altermann, D.R. Nelson, W.U. Mueller and O. Catuneanu, Editors, The Precambrian Earth: Tempos and Events, Elsevier, Amsterdam (2004), pp. 201-213.

Eriksson and Cheney, 1992 P.G. Eriksson and E.S. Cheney, Evidence for the transition to an oxygen-rich atmosphere during the evolution of red beds in the Lower Proterozoic sequences of southern Africa, Precambrian Res. 54 (1992), pp. 257-269.

Eriksson and Fedo, 1994 K.A. Eriksson and C.M. Fedo, Archean cratonic sedimentary successions. In: K.C. Condie, Editor, Archean Crustal Evolution, Elsevier, Amsterdam (1994), pp. 171-204.

Eriksson and Martins-Neto, 2004 P.G. Eriksson and M.A. Martins-Neto, Commentary, Chapter 7. In: P.G. Eriksson, W. Altermann, D.R. Nelson, W.U. Mueller and J. Catuneanu, Editors, The Precambrian Earth: Tempos and Events, Elsevier, Amsterdam (2004), pp. 677-680.

Eriksson and Simpson, 1998 K.A. Eriksson and E.L. Simpson, Controls on spatial and temporal distribution of Precambrian eolianites, Sediment. Geol. 120 (1998), pp. 275294. 
Eriksson et al., 1994 K.A. Eriksson, B. Krapez and P.W. Fralick, Sedimentology of Archean greenstone belts: signatures of tectonic evolution, Earth-Sci. Rev. 37 (1994), pp. $1-88$.

Eriksson et al., 1997 K.A. Eriksson, B. Krapez and P.W. Fralick, Sedimentological aspects. In: M.J. De Wit and L.D. Ashwal, Editors, Greenstone Belts, Clarendon Press, Oxford (1997), pp. 33-54.

Eriksson et al., 1998 P.G. Eriksson, K.C. Condie, H. Tirsgaard, W.U. Mueller, W. Altermann, A.D. Miall, L.B. Aspler, O. Catuneanu and J.R. Chiarenzelli, Precambrian clastic sedimentation systems, Sediment. Geol. 120 (1998), pp. 5-53.

Eriksson et al., 2000 P.G. Eriksson, E.L. Simpson, K.A. Eriksson, A.J. Bumby, G.L. Steyn and S. Sarkar, Muddy roll-up structures in siliciclastic interdune beds of the c. 1.8 Ga Waterberg Group, South Africa, Palaios 15 (2000), pp. 177-183.

Eriksson et al., 2001a P.G. Eriksson, O. Catuneanu, L.B. Aspler, J.R. Chiarenzelli and M.A. Martins-Neto, Preface, special issue: the influence of magmatism, tectonics, sea level change and palaeo-climate on Precambrian basin evolution: change over time, Sediment. Geol. 141/142 (2001), pp. vii-xi.

Eriksson et al., 2001b P.G. Eriksson, M.A. Martins-Neto, D.R. Nelson, L.B. Aspler, J.R. Chiarenzelli, O. Catuneanu, S. Sarkar, W. Altermann, C.J. Rautenbach and W. de, An introduction to Precambrian basins: their characteristics and genesis, Sediment. Geol. 141/142 (2001), pp. 1-35.

Eriksson et al., 2002 P.G. Eriksson, K.C. Condie, W. van der Westhuizen, R. van der Merwe, H. de Bruiyn, D.R. Nelson, W. Altermann, O. Catuneanu, A.J. Bumby, J. Lindsay and M.J. Cunningham, Late Archaean superplume events: a Kaapvaal-Pilbara perspective, J. Geodyn. 34 (2002), pp. 207-247. 
Eriksson et al., 2004a In: P.G. Eriksson, W. Altermann, D.R. Nelson, W.U. Mueller and O. Catuneanu, Editors, The Precambrian Earth: Tempos and Events, Elsevier, Amsterdam (2004) 941 pp..

Eriksson et al., 2004b P.G. Eriksson, A.J. Bumby and M. Popa, Introduction, Chapter 7. In: P.G. Eriksson, W. Altermann, D.R. Nelson, W.U. Mueller and O. Catuneanu, Editors, The Precambrian Earth: Tempos and Events, Elsevier, Amsterdam (2004), pp. 593-602.

Eriksson et al., 2004c P.G. Eriksson, A.J. Bumby and P. Mostert, Early Precambrian epeiric seas. In: P.G. Eriksson, W. Altermann, D.R. Nelson, W.U. Mueller and O. Catuneanu, Editors, The Precambrian Earth: Tempos and Events, Elsevier, Amsterdam (2004), pp. 657-660.

Eriksson et al., 2004d P.G. Eriksson, P.K. Bose, S. Sarkar and S. Banerjee, Sedimentation rates. In: P.G. Eriksson, W. Altermann, D.R. Nelson, W.U. Mueller and O. Catuneanu, Editors, The Precambrian Earth: Tempos and Events, Elsevier, Amsterdam (2004), pp. $675-677$.

Eriksson et al., 2004e P.G. Eriksson, O. Catuneanu, D.R. Nelson, W.U. Mueller and W. Altermann, Towards a synthesis. In: P.G. Eriksson, W. Altermann, D.R. Nelson, W.U. Mueller and O. Catuneanu, Editors, The Precambrian Earth: Tempos and Events, Elsevier, Amsterdam (2004), pp. 739-769.

Eriksson et al., 2005 P.G. Eriksson, O. Catuneanu, S. Sarkar and H. Tirsgaard, Patterns of sedimentation in the Precambrian, Sediment. Geol. 176 (2005), pp. 17-42.

Eriksson et al., 2006 P.G. Eriksson, R. Mazumder, O. Catuneanu, A.J. Bumby and B.O. Ilondo, Precambrian continental freeboard and geological evolution: a time perspective, Earth-Sci. Rev. 79 (2006), pp. 165-204. 
Ernst et al., 2004 R.E. Ernst, K.L. Buchan and A. Prokoph, Large igneous province record through time. In: P.G. Eriksson, W. Altermann, D.R. Nelson, W.U. Mueller and O. Catuneanu, Editors, The Precambrian Earth: Tempos and Events, Elsevier, Amsterdam (2004), pp. 173-180.

Eyles and Januszczak, 2004 N. Eyles and N. Januszczak, 'Zipper-rift': a tectonic model for Neoproterozoic glaciations during the breakup of Rodinia after $750 \mathrm{Ma}$, Earth-Sci. Rev. 65 (2004), pp. 1-73.

Fedo and Eriksson, 1996 C.M. Fedo and K.A. Eriksson, Stratigraphic framework of the $>$ 3.0 Ga Buhwa greenstone belt: a unique stable shelf succession in the Zimbabwe Archean craton, Precambrian Res. 77 (1996), pp. 161-178.

Fedo et al., 2001 C.M. Fedo, J.S. Myers and P.W.U. Appel, Depositional setting and paleogeographic implications of earth's oldest supracrustal rocks, the $>3.7 \mathrm{Ga}$ Isua Greenstone belt, West Greenland, Sediment. Geol. 141/142 (2001), pp. 61-77.

Grotzinger, 1989 J.P. Grotzinger, Facies and evolution of Precambrian carbonate depositional systems: emergence of the modern platform archetype. In: P.D. Crevello, J.L. Wilson, J.F. Sarg and J.F. Read, Editors, Controls on Carbonate Platform and Basin Development, Soc. Econ. Paleontol. Mineral. Spec. Pub. vol. 44, Tulsa, Oklahoma (1989), pp. 79-101.

Grotzinger and Kasting, 1993 J.P. Grotzinger and J.F. Kasting, New constraints of Precambrian ocean composition, J. Geol. 101 (1993), pp. 235-243.

Hassler and Simonson, 2001 S.W. Hassler and B.M. Simonson, The sedimentary record of extraterrestrial impacts in deep shelf environments - evidence from the early Precambrian, J. Geol. 109 (2001), pp. 1-22. 
Hoffman, 1989 P.F. Hoffman, Precambrian geology and tectonic history of North America. In: A.W. Bally and A.R. Palmer, Editors, The Geology of North America, Geol. Soc. Amer. vol. A, Boulder, Colorado (1989), pp. 447-512.

Hoffman et al., 1998 P.F. Hoffman, A.J. Kaufman, G.P. Halverson and D.P. Schrag, A Neoproterozoic snowball Earth, Science 281 (1998), pp. 1342-1346.

Hofmann et al., 2001 A. Hofmann, P. Dirks and H. Jelsma, Late Archaean foreland basin evolution, Belingwe greenstone belt, Zimbabwe, Sediment. Geol. 141/142 (2001), pp. $131-168$.

Holland, 1973 H.D. Holland, The oceans: a possible source of iron in iron-formations, Econ. Geol. 68 (1973), pp. 1169-1172.

Holland, 1984 H.D. Holland, The Chemical Evolution of the Atmosphere and the Oceans, Princeton University Press, Princeton, New Jersey (1984) 582 pp..

Holland, 2002 H.D. Holland, Volcanic gases, black smokers, and the great oxidation event, Geochim. Cosmochim. Acta 66 (2002), pp. 3811-3826.

Ingersoll, 1988 R.V. Ingersoll, Tectonics of sedimentary basins, Geol. Soc. Amer. Bull. 100 (1988), pp. 1704-1719.

Karhu and Holland, 1996 J.A. Karhu and H.D. Holland, Carbon isotopes and the rise of atmospheric oxygen, Geology 24 (1996), pp. 867-870.

Kasting and Siefert, 2002 J.F. Kasting and J.L. Siefert, Life and the evolution of Earth's atmosphere, Science 296 (2002), pp. 1066-1068.

Kazmierczak et al., 2004 J. Kazmierczak, S. Kempe and W. Altermann, Microbial origin of Precambrian carbonates: lessons from modern analogues. In: P.G. Eriksson, W. 
Altermann, D.R. Nelson, W.U. Mueller and O. Catuneanu, Editors, The Precambrian Earth: Tempos and Events, Elsevier, Amsterdam (2004), pp. 545-564.

Kirschvink, 1992 J.L. Kirschvink, Late proterozoic low-latitude global glaciation: the snowball Earth. In: J.W. Schopf and C. Klein, Editors, The Proterozoic Biosphere: A Multidisciplinary Study, Cambridge University Press, Cambridge (1992), pp. 51-52.

Klein and Beukes, 1989 C. Klein and N.J. Beukes, Geochemistry and sedimentology of a facies transition from limestone to iron-formation deposition in the early Proterozoic Transvaal Supergroup, South Africa, Econ. Geol. 84 (1989), pp. 1733-1774.

Krapez and Barley, 1987 B. Krapez and M.E. Barley, Archaean strike-slip faulting and related ensialic basins: evidence from the Pilbara Block, Australia, Geol. Mag. 124 (1987), pp. 555-567.

Lasaga and Ohmoto, 2002 A.C. Lasaga and H. Ohmoto, The oxygen geochemical cycle: dynamics and stability, Geochim. Cosmochim. Acta 66 (2002), pp. 361-381.

Lindsay and Brasier, 2002 J.F. Lindsay and M.D. Brasier, Did global tectonics drive early biosphere evolution? Carbon isotope record from 2.6 to 1.9 Ga carbonates of Western Australian basins, Precambrian Res. 114 (2002), pp. 1-34.

Lindsay and Brasier, 2004 J.F. Lindsay and M.D. Brasier, The evolution of the Precambrian atmosphere: carbon isotopic evidence from the Australian continent. In: P.G. Eriksson, W. Altermann, D.R. Nelson, W.U. Mueller and O. Catuneanu, Editors, The Precambrian Earth: Tempos and Events, Elsevier, Amsterdam (2004), pp. 388-403.

Long, 2004 D.G.F. Long, Precambrian rivers. In: P.G. Eriksson, W. Altermann, D.R. Nelson, W.U. Mueller and O. Catuneanu, Editors, The Precambrian Earth: Tempos and Events, Elsevier, Amsterdam (2004), pp. 660-663. 
Lowe, 1983 D.R. Lowe, Restricted shallow-water sedimentation of Early Archaean stromatolitic and evaporitic strata of the Strelley Pool Chert, Pilbara Block, Western Australia, Precambrian Res. 19 (1983), pp. 239-283.

Lowe, 1994 D.R. Lowe, Archean greenstone-related sedimentary rocks. In: K.C. Condie, Editor, Archean Crustal Evolution, Elsevier, Amsterdam (1994), pp. 121-169.

Lyons et al., 2004 T.W. Lyons, L.C. Kah and A.M. Gellatly, The Precambrian sulphur isotope record of evolving atmospheric oxygen. In: P.G. Eriksson, W. Altermann, D.R. Nelson, W.U. Mueller and O. Catuneanu, Editors, The Precambrian Earth: Tempos and Events, Elsevier, Amsterdam (2004), pp. 421-440.

Martin and Moyen, 2002 H. Martin and J.F. Moyen, Secular changes in tonalitetrondhjemite-granodiorite composition as markers of the progressive cooling Earth, Geology 30 (2002), pp. 319-322.

McLennan and Taylor, 1991 S.M. McLennan and S.R. Taylor, Sedimentary rocks and crustal evolution: tectonic setting and secular trends, J. Geol. 1 (1991), pp. 1-21.

Mojzsis et al., 2001 S.J. Mojzsis, T.M. Harrison and R.T. Pidgeon, Oxygen-isotope evidence from ancient zircons for liquid water at the Earth's surface 4,300 Myr ago, Nature 409 (2001), pp. 178-181.

Mueller and Corcoran, 1998 W.U. Mueller and P.L. Corcoran, Late-orogenic basins in the Archaean Superior Province, Canada: characteristics and inferences, Sediment. Geol. 120 (1998), pp. 177-203.

Mueller and Corcoran, 2001 W.U. Mueller and P.L. Corcoran, Volcano-sedimentary processes operating on a marginal continental arc: the Archean Raquette Lake Formation, Slave Province, Canada, Sediment. Geol. 141/142 (2001), pp. 169-204. 
Mueller et al., 2002 W.U. Mueller, P.L. Corcoran and J.A. Donaldson, Sedimentology of a tide- and wave-influenced high-energy Archaean coastline: the Jackson Lake Formation, Slave Province, Canada. In: W. Altermann and P.L. Corcoran, Editors, Precambrian Sedimentary Environments: A Modern Approach to Ancient Depositional Systems, Blackwell, Oxford (2002), pp. 153-182.

Mukhin and Pinenov, 2002 L.M. Mukhin and K.Yu. Pinenov, Impact hot spots on the cold surface of the early Earth, Planet. Space Sci. 50 (2002), pp. 41-43.

Nelson, 1998 D.R. Nelson, Granite-greenstone crust formation on the Archaean Earth—a consequence of two superimposed processes, Earth Planet. Sci. Lett. 158 (1998), pp. $109-119$.

Nelson, 2004 D.R. Nelson, Earth's formation and first billion years. In: P.G. Eriksson, W. Altermann, D.R. Nelson, W.U. Mueller and O. Catuneanu, Editors, The Precambrian Earth: Tempos and Events, Elsevier, Amsterdam (2004), pp. 3-27.

Nelson et al., 1999 D.R. Nelson, A.F. Trendall and W. Altermann, Chronological correlations between the Pilbara and Kaapvaal cratons, Precambrian Res. 97 (1999), pp. $165-189$.

Ohmoto, 2004 H. Ohmoto, The Archaean atmosphere, hydrosphere and biosphere. In: P.G. Eriksson, W. Altermann, D.R. Nelson, W.U. Mueller and O. Catuneanu, Editors, The Precambrian Earth: Tempos and Events, Elsevier, Amsterdam (2004), pp. 361-388.

Ojakangas, 1985 R.W. Ojakangas, Review of Archean clastic sedimentation, Canadian Shield: major elsic volcanic contributions to turbidite and alluvial fan-fluvial facies associations. In: L.D. Ayres, P.C. Thurston, K.D. Card and W. Weber, Editors, Evolution of Archean Supracrustal Sequences, Geol. Assoc. Can. Spec. Pap. vol. 28 (1985), pp. 2347. 
Page, 1981 N.J. Page, The precambrian diamictite below the base of the stillwater complex, Montana. In: M.J. Hambrey and W.B. Harland, Editors, Earth's PrePleistocene Glacial Record, Cambridge Univ. Press, Cambridge (1981), pp. 821-823.

Peltier et al., 1997 W.R. Peltier, S. Butler and L.P. Solheim, The influence of phase transformations on mantle mixing and plate tectonics. In: D.J. Crossley, Editor, Earth's Deep Interior, Gordon and Breach, Amsterdam (1997), pp. 405-430.

Ryder, 2003 G. Ryder, Bombardment of the Hadean Earth: wholesome or deleterious?, Astrobiology 3 (2003), pp. 3-6.

Sarkar et al., 2005 S. Sarkar, S. Banerjee, P.G. Eriksson and O. Catuneanu, Microbial mat control on siliciclastic Precambrian sequence stratigraphic architecture: examples from India, Sediment. Geol. 176 (2005), pp. 195-209.

Schieber, 1998 J. Schieber, Possible indicators of microbial mat deposits in shales and sandstones: examples from the Mid-Proterozoic Belt Supergroup, Montana, USA, Sediment. Geol. 120 (1998), pp. 105-124.

Schieber, 2004 J. Schieber, Microbial mats in the siliciclastic rock record: a summary of diagnostic features. In: P.G. Eriksson, W. Altermann, D.R. Nelson, W.U. Mueller and O. Catuneanu, Editors, The Precambrian Earth: Tempos and Events, Elsevier, Amsterdam (2004), pp. 663-673.

Schopf, 2004 J.W. Schopf, Earth's earliest biosphere: status of the hunt. In: P.G. Eriksson, W. Altermann, D.R. Nelson, W.U. Mueller and O. Catuneanu, Editors, The Precambrian Earth: Tempos and Events, Elsevier, Amsterdam (2004), pp. 516-539.

Simpson et al., 2004a E.L. Simpson, F.F. Alkmim, P.K. Bose, A.J. Bumby, K.A. Eriksson, P.G. Eriksson, M.A. Martins-Neto, L.T. Middleton and R.H. Rainbird, Sedimentary dynamics of Precambrian aeolianites. In: P.G. Eriksson, W. Altermann, 
D.R. Nelson, W.U. Mueller and O. Catuneanu, Editors, The Precambrian Earth: Tempos and Events, Elsevier, Amsterdam (2004), pp. 642-657.

Simpson et al., 2004b E.L. Simpson, K.A. Eriksson, C.A. Kuklis, P.G. Eriksson, A.J. Bumby and C.F. van Jaarsveld, A $\sim 1.8$ Ga Playa Deposit in the Makgabeng Formation, Waterberg Group, South Africa, Sediment. Geol. 163 (2004), pp. 279-292.

Smithies et al., 2001 R.H. Smithies, D.R. Nelson and G. Pike, Development of the Archaean Mallina Basin, Pilbara Craton, northwestern Australia: a study of detrital and inherited zircon ages, Sediment. Geol. 141/142 (2001), pp. 79-94.

Taylor and McLennan, 1985 S.R. Taylor and S.M. McLennan, The Continental Crust: Its Composition, and Evolution, Blackwell, Oxford (1985) 312 pp..

Trendall, 2002 A.F. Trendall, The significance of iron-formation in the Precambrian stratigraphic record. In: W. Altermann and P.L. Corcoran, Editors, Precambrian Sedimentary Environments: A Modern Approach to Depositional Systems, I.A.S. Spec. Publ. vol. 44, Blackwell, Oxford (2002), pp. 33-66.

Trendall and Blockley, 2004 A.F. Trendall and J.G. Blockley, Precambrian ironformation. In: P.G. Eriksson, W. Altermann, D.R. Nelson, W.U. Mueller and O. Catuneanu, Editors, The Precambrian Earth: Tempos and Events, Elsevier, Amsterdam (2004), pp. 403-421.

Veizer, 1983 J. Veizer, Geologic evolution of the Archean-Early Proterozoic earth. In: J.W. Schopf, Editor, Earth's Earliest Biosphere: Its Origin and Evolution, Princeton University Press, Princeton, New Jersey (1983), pp. 240-259.

Von Brunn and Gold, 1993 V. Von Brunn and D.J.D. Gold, Diamictite in the Archean Pongola sequence of southern Africa, J. Afr. Earth Sci. 16 (1993), pp. 367-374. 
Walker, 1977 J.C.G. Walker, Evolution of the Atmosphere, Macmillian, New York (1977) $318 \mathrm{pp}$.

Walter, 1983 M.R. Walter, Archean stromatolites: evidence of the Earth's earliest benthos. In: J.W. Schopf, Editor, Earth's Earliest Biosphere, its Origin and Evolution, Princeton Univ. Press, Princeton, New Jersey (1983), pp. 187-213.

Wilde et al., 2001 S.A. Wilde, J.W. Valley, W.H. Peck and C.M. Graham, Evidence from detrital zircons for the existence of continental crust and oceans on the Earth 4.4 Gyr ago, Nature 409 (2001), pp. 175-178.

Williams, 1975 G.E. Williams, Late Precambrian glacial climate and the Earth's obliquity, Geol. Mag. 112 (1975), pp. 441-465.

Williams, 1993 G.E. Williams, History of the Earth's obliquity, Earth-Sci. Rev. 34 (1993), pp. 1-45.

Williams, 2004a G.E. Williams, Earth's Precambrian rotation and the evolving lunar orbit: implications of tidal rhythmite data for palaeogeophysics. In: P.G. Eriksson, W. Altermann, D.R. Nelson, W.U. Mueller and O. Catuneanu, Editors, The Precambrian Earth: Tempos and Events, Elsevier, Amsterdam (2004), pp. 473-482.

Williams, 2004b G.E. Williams, The paradox of Proterozoic glaciomarine deposition, open seas and strong seasonality near the Palaeo-Equator: global implications. In: P.G. Eriksson, W. Altermann, D.R. Nelson, W.U. Mueller and O. Catuneanu, Editors, The Precambrian Earth: Tempos and Events, Elsevier, Amsterdam (2004), pp. 448-459.

Windley, 1995 B.F. Windley, The Evolving Continents (3rd ed.), John Wiley, Chichester (1995) $526 \mathrm{pp}$.

Wright and Altermann, 2000 D.T. Wright and W. Altermann, Microfacies development in Late Archaean stromatolites and oolites of the Campbellrand Subgroup, South Africa. 
In: E. Insalco, P.W. Skelton and T.J. Palmer, Editors, Carbonate Platform Systems. Components and Interactions, Geol. Soc. London Spec. Publ. vol. 178 (2000), pp. 51-70.

Young, 1991 G.M. Young, The geologic record of glaciation: relevance to the climatic history of the Earth, Geosci. Can. 18 (1991), pp. 100-108.

Young, 2002 G.M. Young, Stratigraphic and tectonic settings of Proterozoic glaciogenic rocks and banded iron-formations: relevance to the snowball Earth debate, J. Afr. Earth Sci. 35 (2002), pp. 451-466.

Young, 2004 G.M. Young, Earth's two great Precambrian glaciations: aftermath of the "Snowball Earth" hypothesis. In: P.G. Eriksson, W. Altermann, D.R. Nelson, W.U. Mueller and O. Catuneanu, Editors, The Precambrian Earth: Tempos and Events, Elsevier, Amsterdam (2004), pp. 440-448.

Zegers and Van Keken, 2001 T.E. Zegers and P.E. Van Keken, Middle Archean continent formation by crustal delamination, Geology 29 (2001), pp. 1083-1086. 